\title{
Curie Point Depth variations to infer thermal structure of the crust at the African-Eurasian convergence zone, SW Turkey
}

\author{
M. Nuri Dolmaz ${ }^{1}$, Timur Ustaömer ${ }^{2}$, Z. Mumtaz Hisarli ${ }^{3}$, and Naci Orbay ${ }^{3}$ \\ ${ }^{1}$ Department of Geophysical Engineering, Suleyman Demirel University, 32260, Isparta, Turkey \\ ${ }^{2}$ Department of Geological Engineering, Istanbul University, Avcilar 34850, Istanbul, Turkey \\ ${ }^{3}$ Department of Geophysical Engineering, Istanbul University, Avcilar 34850, Istanbul, Turkey
}

(Received September 11, 2004; Revised April 18, 2005; Accepted April 19, 2005)

\begin{abstract}
We examined the thermal structure of the crust across complex deformation zones in SW Turkey using the Curie Point Depth (CPD) estimates and made comparisons of the thermal state of the crust with the seismic activity to provide insights for spatial limits of brittle failure in this region. The CPD estimates of SW Turkey from 80 overlapping blocks vary from 9 to $20 \mathrm{~km}$. SW Turkey has two regions of shallow CPD. The shallow CPD region in the Uşak-Afyon zone in western part of the study area is caused by upper crustal thinning and shallowing of high conductivity lower crust. The other shallow CPD region is in the Central Anatolian Volcanic Province in the eastern part of the study area and is thought to be related to the presence of silicate melts in the shallow-level crust. A NNW-SSE trending belt of deep CPD region separates these two zones and is located along the boundary of high (west) and low (east) seismic activities. It is interpreted that the regional thermal structure in SW Turkey is mainly controlled by the processes associated with the African-Eurasian plate convergence zone. The N-S lithospheric extension above the subducting slab created a thermal dome in Western Anatolia in response to upwelling of asthenosphere. Post-collisional magmatism of Neogene-Quaternary age generated another thermal dome in the eastern area. Comparison of the CPD variations with the seismic activity has shown that large earthquakes occur near the margins of the inferred regional thermal domes. Low seismic activity within the regionally active seismic areas seems to be associated with shallow CPD and high heat flow.
\end{abstract}

Key words: Curie Point Depth (CPD), thermal structure, SW Turkey, aeromagnetic data, seismicity.

\section{Introduction}

Thermal structure of the crust determines modes of deformation, depths of brittle and ductile deformation zones, regional heat flow variations, seismicity, subsidence/uplift patterns and maturity of organic matter in sedimentary basins. One of the methods of examining thermal structure of the crust is the estimation of the CPD, using aeromagnetic data. The CPD is known as the depth at which the dominant magnetic mineral in the crust passes from a ferromagnetic state to a paramagnetic state under the effect of increasing temperature (Nagata, 1961). For this purpose, the basal depth of a magnetic source from aeromagnetic data is considered to be the CPD. Thermal structure of the crust involving CPD estimations have been published for various tectonic settings (e.g., Vacquier and Affleck, 1941; Smith et al., 1974, 1977; Bhattacharyya and Leu, 1975; Byerly and Stolt, 1977; Shuey et al., 1977; Blakely and Hassanzadeh, 1981; Connard et al., 1983; Okubo et al., 1985, 1989; Blakely, 1988; Okubo and Matsunaga, 1994; Hisarli, 1996; Banerjee et al., 1998; Tanaka et al., 1999; Badalyan, 2000; Dolmaz et al., 2005).

Active deformation of Turkey is controlled by the African-Eurasian plate convergence zone (Fig. 1). The con-

Copy right(c) The Society of Geomagnetism and Earth, Planetary and Space Sciences (SGEPSS); The Seismological Society of Japan; The Volcanological Society of Japan; The Geodetic Society of Japan; The Japanese Society for Planetary Sciences; TERRAPUB vergence zone is marked by the Hellenic trench and arc in the west and the Bitlis-Zagros Suture Zone further east in SE Anatolia (Şengör and Yilmaz, 1981; Dewey et al., 1986; Y1lmaz et al., 1993). The collision of the Arabian Platform with Anatolia along this suture zone commenced in Early Miocene and the convergence is continuing today at a rate of $6 \mathrm{~mm} / \mathrm{y}$ (Reilinger et al., 1997; McClusky et al., 2000). Two transform faults were formed in the Late Miocene-Pliocene period to accommodate westward tectonic escape of the Anatolian Plate from the collision front (McKenzie, 1972, 1978; Şengör and Yılmaz, 1981; Barka, 1992); the dextral North Anatolian Transform Fault Zone (NATFZ) and the sinistral East Anatolian Transform Fault Zone (EATFZ, Fig. 1). The western part of the Anatolian Plate rotates anti-clockwise and moves southward towards the Hellenic trench at a rate of ca. $30 \mathrm{~mm} / \mathrm{y}$ and forms one of the most rapidly extending areas of the world (Reilinger et al., 1997; McClusky et al., 2000). The extending region terminates gradually in the central part of the Anatolian Plate to the north of the Cyprus margin. This area, known as the "Ova Province" (Şengör and Yılmaz, 1981), shows little seismicity, indicating low internal deformation and coherent motion of the Anatolian Plate (Taymaz et al., 1991; Saunders et al., 1998).

In this paper, we describe thermal structure of the crust in SW Anatolia across the West Anatolian Extensional Province in the west and the "Ova Province" in the east. A 


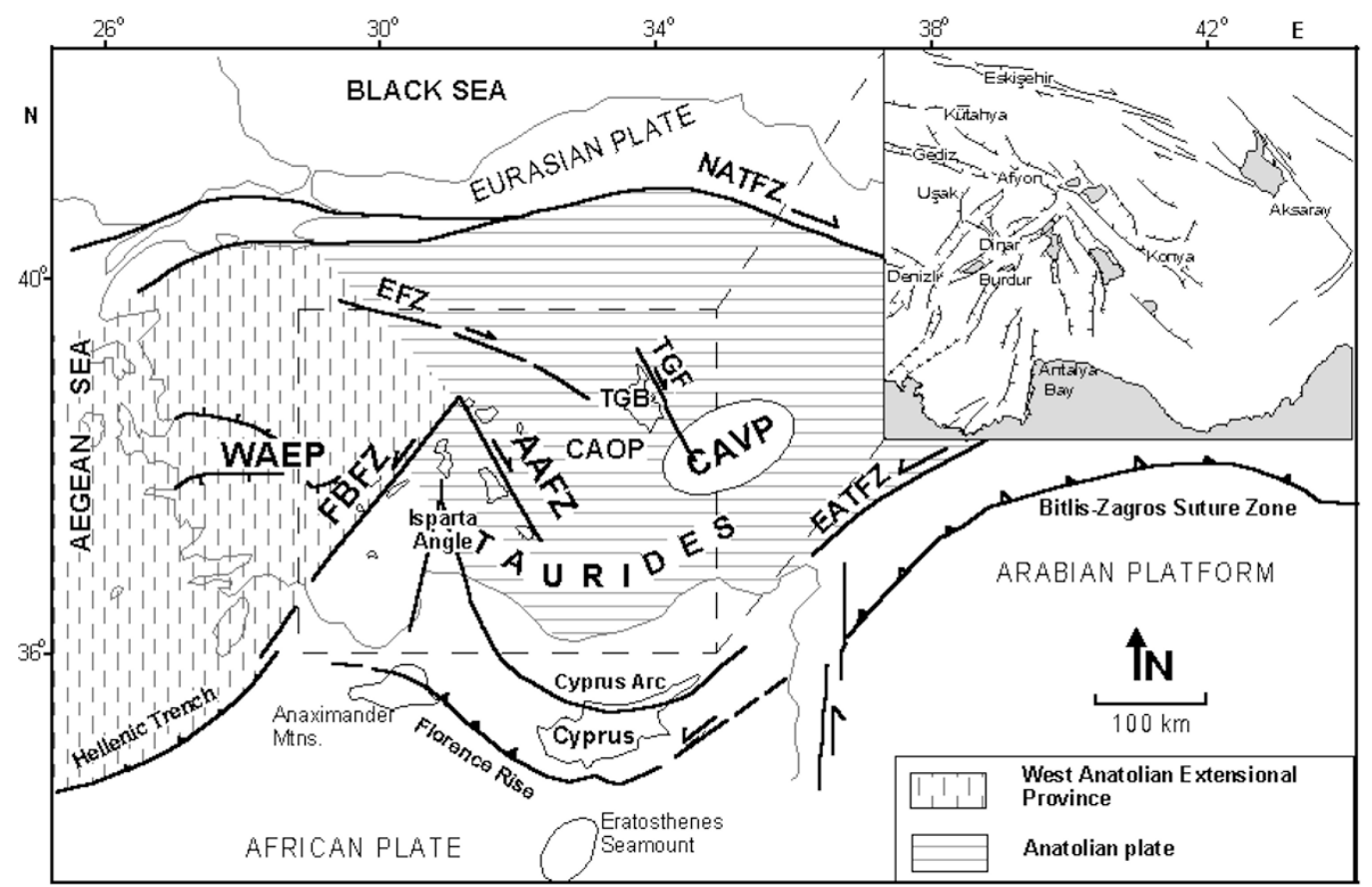

Fig. 1. Simplified tectonic map of Turkey and adjoining regions, showing the African-Eurasian plate boundary and the neotectonic provinces (modified after McKenzie, 1972, 1978; Şengör and Yllmaz, 1981; Barka, 1992; Reilinger et al., 1997; McClusky et al., 2000). The dashed rectangle shows the location of the study area, structural details of which are given in the inset (modified after Bozkurt, 2001). Abbreviations: NATFZ, North Anatolian Transform Fault Zone; EATFZ, East Anatolian Transform Fault Zone; FBFZ, Fethiye-Burdur Fault Zone; AAFZ, Afyon-Akşehir Fault Zone; EFZ, Eskişehir Fault Zone; TGF, Tuz Gölü Fault; TGB, Tuz Gölü Basin; WAEP, West Anatolian Extensional Province; CAVP, Central Anatolian Volcanic Province; CAOP, Central Anatolian Ova Province. Coastlines and lakes are also shown.

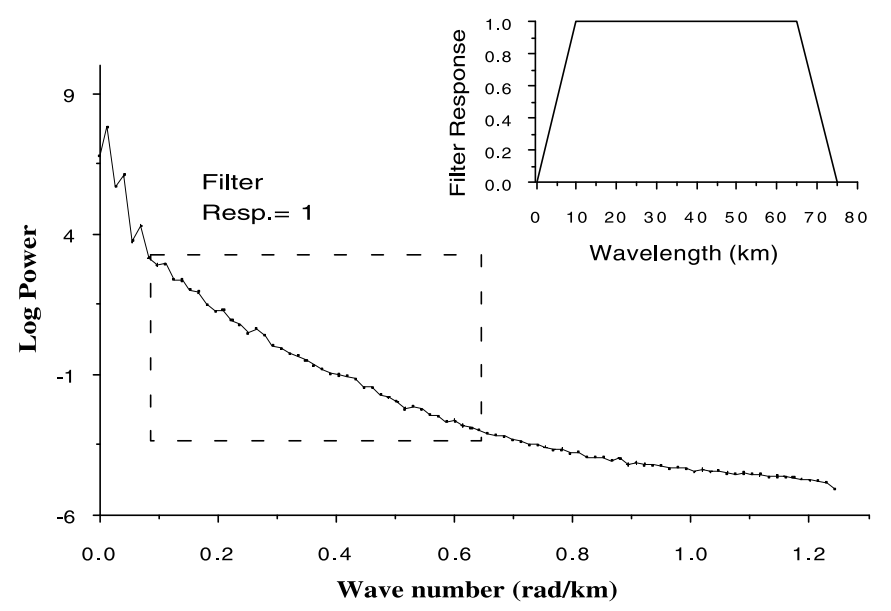

Fig. 2. Azimuthally averaged log power spectrum of the reduced to pole data. The box represents the band-pass filter amplitude response. The response function of the band-pass filter is also shown.

power spectrum technique was applied to the aeromagnetic data in order to estimate the CPD in this region. We show that the boundary between the two zones is characterized by a ca. $100 \mathrm{~km}$ wide, NNW-SSE trending low heat flow zone. We also demonstrate here that the regions of hotter crust in SW Anatolia are characterized by lower seismic activity.

\subsection{Geological setting}

The West Anatolian Extensional Province (WAEP) is bordered by the North Anatolian Transform Fault (NATF) in the north, the dextral Eskişehir Fault Zone (EFZ) and the Afyon-Akşehir Fault Zone (AAFZ) in the east and the sinistral Fethiye-Burdur Fault Zone (FBFZ) in the south (Fig. 1). The intense seismic activity in the WAEP is confined to
NE-SW and WNW-ESE trending narrow fault zones that are characterized by normal or oblique-slip normal faults (Bozkurt, 2001). The horst blocks bordered by these fault zones in the WAEP are aseismic or show little, dispersed seismic activity. The seismically active extensional terrain in the west is bordered by an aseismic or low seismicity region towards the Central Anatolian Ova Province (CAOP). The CAOP is located at the hinterland of the Cyprus-Eratosthenes Seamount collision zone and is characterized by a thicker crust, presence of thick and wide Neogene Basins and Plio-Quaternary volcanoes (Anastasakis and Kelling, 1991; Robertson, 1998). The CAOP, characterized by low seismic activity, is a vast flat terrain, bordered 


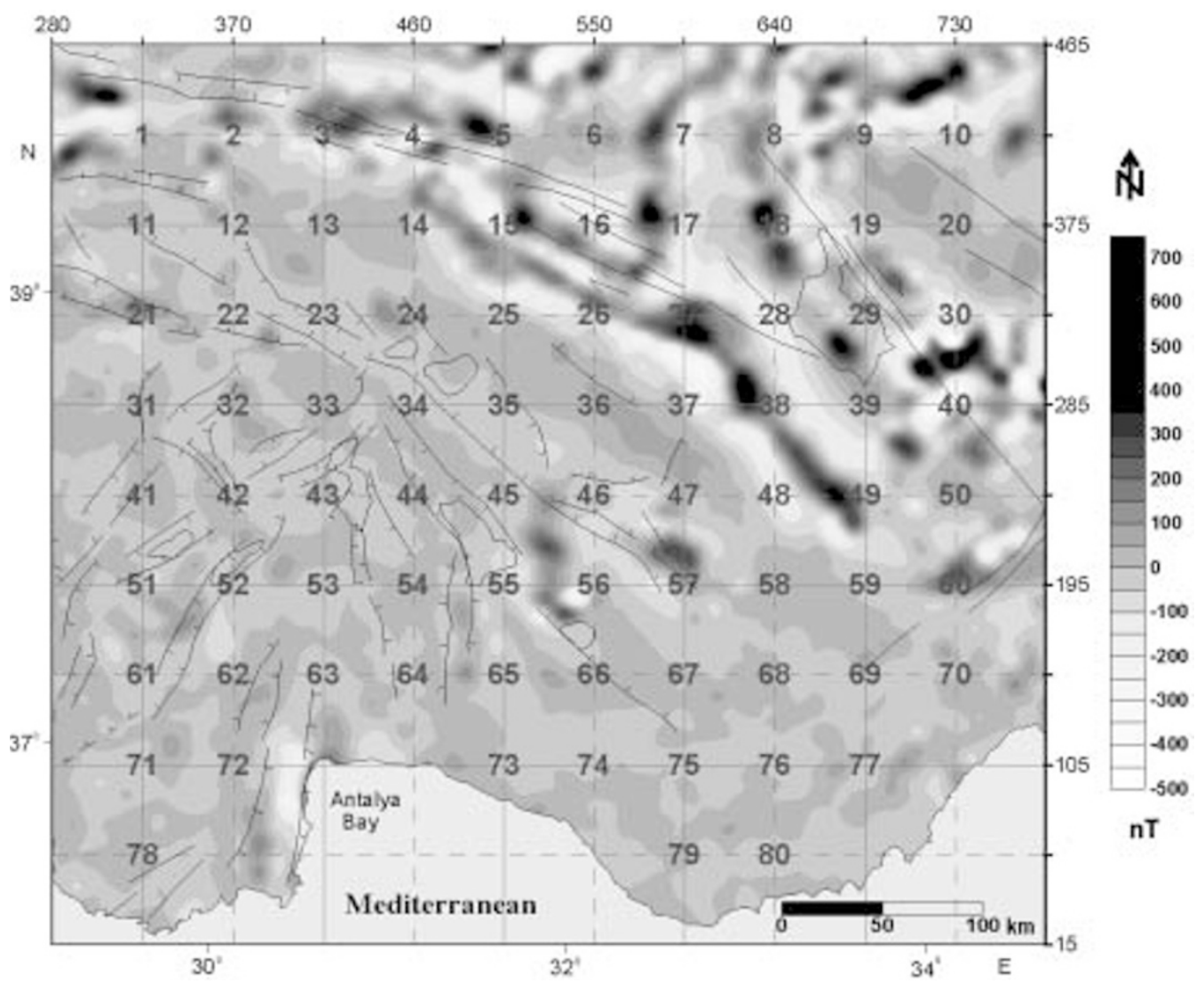

Fig. 3. The band-pass (full pass $10-65 \mathrm{~km}$ ) filtered map, used for the CPD calculations. The map was subdivided into 80 overlapping blocks $(90 \times 90$ $\mathrm{km})$. Each block is denoted by a number at its center. Locations of the faults are also shown.

by the dextral Tuz Gölü Fault (TGF) in the east (Fig. 1). This flat terrain is underlain by a major Neogene intracontinental basin (i.e. the Tuz Gölü Basin; Görür et al., 1984; Şengör et al., 1985; Çemen et al., 1999; Fig. 1). An ophiolitic suture zone, the Inner-Tauride Suture, is thought to exist beneath the Tuz Gölü Basin (TGB; Fig. 1). The total thickness of sediments within the TGB reaches ca. $10 \mathrm{~km}$ (Görür et al., 1984; Gürbüz and Evans, 1991). The area to the east and southeast of the TGF comprises metamorphic rocks and Neogene-Quaternary volcanoes. The volcanoes form the highest mountains in this region and constitute a wide volcanic province, known as the Central Anatolian Volcanic Province (CAVP; Pasquare et al., 1988; Toprak and Göncüoğlu, 1993; Le Pennec et al., 1994; Tankut et al., 1998; Aydar and Gourgaud, 2002). The Neogene and Quaternary CAVP represents magmatism related to the continental collision between the Afro-Arabian and Eurasian plates (Pasquare et al., 1988). The CAOP is bordered to the south by the mountains of the Taurus belt (Fig. 1). The Taurides comprises a series of nappe piles formed in the Late Mesozoic to Mid-Miocene period (Özgül, 1976; Özkaya, 1990; Özgül et al., 1991; Andrew and Robertson, 2002).

\subsection{Previous geophysical studies}

Preliminary heat flow data of Tezcan (1979) and Tezcan and Turgay (1989) show some regional heat flow anomalies of above $120 \mathrm{~mW} / \mathrm{m}^{2}$ in the WAEP. The mean value of heat flow for Western Anatolia is $107 \pm 45 \mathrm{~mW} / \mathrm{m}^{2}$ based on the silica geothermometry and $97 \pm 27 \mathrm{~mW} / \mathrm{m}^{2}$ for the conventional heat flow data. These values are $60 \%$ above the world average (İlkışık, 1995). Central Anatolia has a range of heat flow anomalies between 20 to $100 \mathrm{~mW} / \mathrm{m}^{2}$ (Tezcan and Turgay, 1989). Heat flow values based on silica geothermometry vary between 66 and $247 \mathrm{~mW} / \mathrm{m}^{2}$ (İlkış1k, $1995)$ in this region. The mean heat flow value using both the silica and gradient techniques is about $158 \pm 35 \mathrm{mWm}^{-2}$ in the CAVP (İlkışık et al., 1997).

The resistivity model for a NW-SE profile from magnetotelluric (MT) data in SW Anatolia provided invaluable insight concerning the variation in depth of the transition from resistive upper crust to conductive lower crust (Gürer et al., 2004). The southern part is characterized by a thick (40-50 $\mathrm{km}$ ) resistive (>2000 $\Omega \mathrm{m}$ ) upper crust and thin conductive lower crust. On the other hand, the northern part is characterized by a thin $(10 \mathrm{~km})$ resistive upper crust and a highly conductive $(10 \Omega \mathrm{m})$ lower crust.

From structural studies and seismic strain rates the stretching factor of the crust across Western Anatolia has been estimated to be ca. 1.25 (Eyidoğan, 1988; Paton, 1992). The unstretched crust in Central Anatolia is ca. 38 $\mathrm{km}$ thick. The crust thins westward to $34 \mathrm{~km}$ near Uşak, and $22 \mathrm{~km}$ in the Aegean Sea (Saunders et al., 1998).

\section{Aeromagnetic Data and Processing Techniques}

The aeromagnetic data were collected by the Mining and Research Exploration Company of Turkey (MTA) along flight lines spaced at $1-3 \mathrm{~km}$ profile intervals at an elevation of $600 \mathrm{~m}$ above ground level in period of 1978-1989. The direction of the flights was perpendicular to the regional 

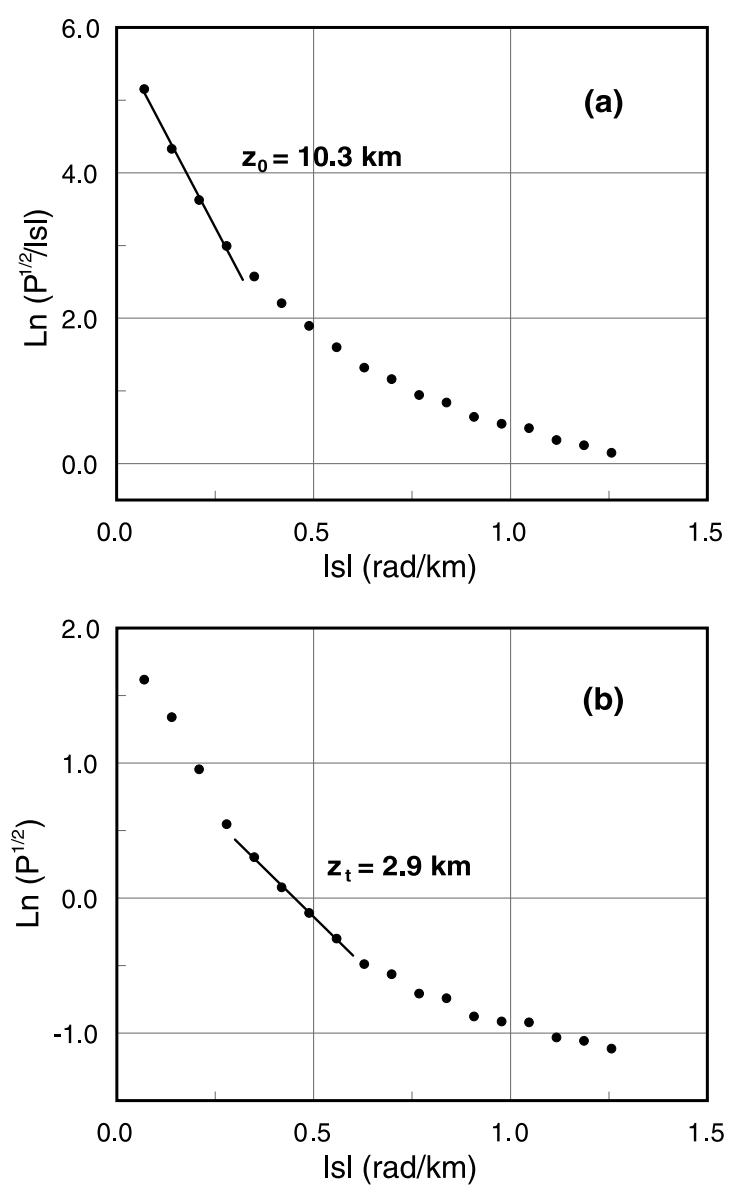

Fig. 4. Examples of power spectrum for estimation of the CPD using the two dimensional magnetic anomaly data of the block, number 63 (see Fig. 3 for location). 10.3 and $2.9 \mathrm{~km}$ are obtained as the centroid and the top bound using the gradient of spectra defined as $\ln \left(P^{1 / 2} /|s|\right)$ and $\ln \left(P^{1 / 2}\right)$, where $|s|$ is the wavenumber and $P(s)$ is the radially averaged power spectrum.

strike of the Taurides (generally N-S) (Aydin and Karat, 1995; Ates et al., 1999). The International Geomagnetic Reference Field (IGRF) for the 1982.5 was then subtracted from the data, which was provided by the MTA, using the program of Malin and Barraclough (1981). Afterwards, the data were interpolated to a square grid with spacing $2.5 \mathrm{~km}$ and the matrix was $450 \times 495 \mathrm{~km}^{2}$ (Dolmaz, 2004). Subsequently, the total field aeromagnetic data were reduced to the (north) magnetic pole using FFTFIL program (Hildenbrand, 1983). The "reduced to pole" data contain both long wavelength and small wavelength anomalies.

Spector and Grant (1970), analyzing statistical properties of patterns of magnetic anomalies, have proven the relationship between the spectrum of observed anomalies and depth of a magnetic source by transforming the spatial data into frequency domain. Spector and Grant (1970)'s method was based on the assumption that the sources were considered to be independent collections of rectangular vertical prisms. For random magnetization, the radial average of the power spectrum of magnetization is constant. Shuey et al. (1977) suggested that the method of Spector and Grant (1970) was more suitable for regional application of magnetic anomalies. Okubo et al. (1985) emphasize that the rectangular prism is an appropriate geometry from which to develop the necessary theory, not from a required geologic model. The method used here resembles the methods of Spector and Grant (1970) and Okubo et al. (1985), which examine the spectral knowledge included in subregions of magnetic data. Spector and Grant (1970) showed that the expected spectrum of an ensemble model was the same as that of a single prism with the average parameters for the collection.

Briefly, CPD $\left(z_{b}\right)$ is estimated in two steps as suggested by Bhattacharyya and Leu (1975) and Okubo et al. (1985). The first is the depth to the centroid $\left(z_{0}\right)$ of the magnetic source from the slope of the longest wavelength part of the spectrum,

$$
\ln \left[\frac{P(s)^{1 / 2}}{|s|}\right]=\ln A-2 \pi|s| z_{0}
$$

where $P(s)$ is the radially averaged power spectrum of the anomaly, $|s|$ is the wavenumber, and $A$ is a constant. The second step is the estimation of the depth to the top boundary $\left(z_{t}\right)$ of that distribution from the slope of the second longest wavelength spectral segment (Okubo et al., 1985),

$$
\ln \left[P(s)^{1 / 2}\right]=\ln B-2 \pi|s| z_{t}
$$

where $B$ is a sum of constants independent of $|s|$. Then the basal depth $\left(z_{b}\right)$ of the magnetic source is calculated from the equation $z_{b}=2 z_{0}-z_{t}$. Bottom depth $\left(z_{b}\right)$ can only be estimated if centroid $\left(z_{0}\right)$ can be accurately determined. The obtained basal depth of a magnetic source is assumed to be the CPD.

Consequently, the CPD estimates involve three stages as follows:

1) division into overlapping square subregions,

2) calculation of the radially averaged log power spectrum for each subregion,

3) estimation of the CPD from the centroid and the top depth estimated from the magnetic source for each subregion.

\section{Data Processing}

The CPD of SW Turkey are determined from detailed analyses of the aeromagnetic data. Many studies confirming derivation of the bottom depth from magnetic data stated that long-wavelength anomalies necessarily originate only from deep-seated sources. The CPD estimation requires also the deepest magnetic sources. The azimuthally averaged log power spectrum of the reduced to pole data was then computed (Fig. 2). Major long wavelength components arising from topography, regional features and magnetic core fields could affect the centroid depth estimates (Okubo et al., 1985; Tsokas et al., 1998; Stampolidis and Tsokas, 2002). Tanaka et al. (1999) suggest that CPD are obtained from using wavelengths longer than $10 \mathrm{~km}$. In order to emphasize the effect of deep sources, the small wavelength anomalies must be removed from the anomaly data. For this purpose, a simple band-pass filter (full pass $10-65 \mathrm{~km}$ ) was designed from the response function of the power spectrum of the reduced pole data (Fig. 2) and was applied to these data by using the FFTFIL (Hildenbrand, 


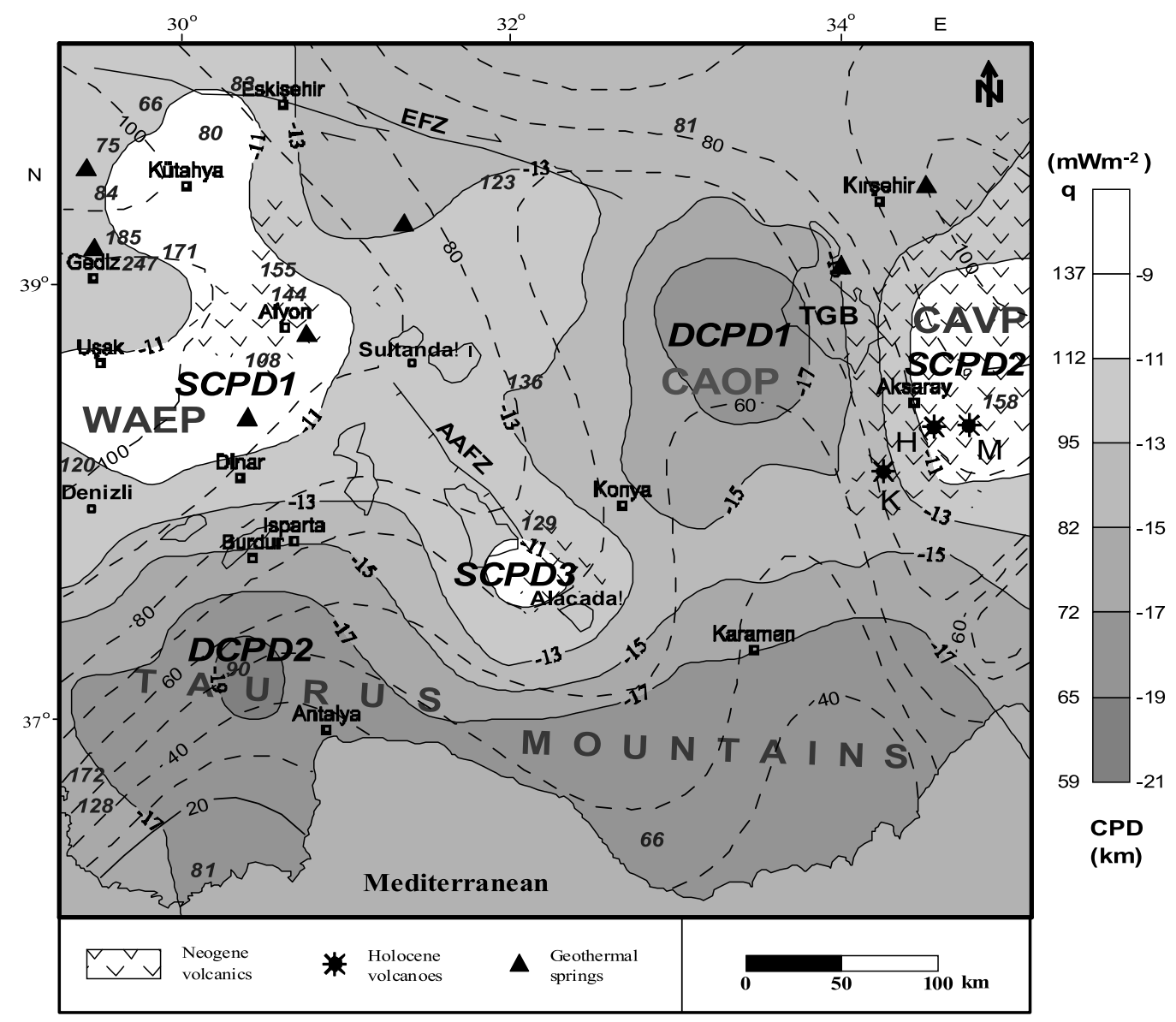

Fig. 5. The CPD map of the study area. Contours are drawn at $2 \mathrm{~km}$ intervals. The corresponding heat flows calculated from the CPD data are given in the scale bar. Dashed lines indicate the heat flow contours calculated by Tezcan and Turgay (1989), while the italic numbers show heat flow values according to İlkışık (1995) and İlkışık et al. (1997). Locations of geothermal springs are also marked (modified from Şimşek, 2001). Abbreviations: AAFZ, Afyon-Akşehir Fault Zone; EFZ, Eskișehir Fault Zone; TGB, Tuz Gölü Basin; WAEP, West Anatolian Extensional Province; CAVP, Central Anatolian Volcanic Province; CAOP, Central Anatolian Ova Province; K, Karacadağ; H, Hasandă̆; M, Melendiz volcanoes. SCPD: shallow CPD, DCPD: deep CPD. See text for explanation.

1983) again. The filtered data used for the CPD estimation are illustrated in Fig. 3.

The choice of the dimensions of square sub-blocks to be used for estimating the CPD explained by Okubo et al. (1985) implies that a minimum ratio of 12:1 and 13:1 of block size to magnetic source is necessary for reasonable estimates. On the other hand because of the limited depth extent of crustal magnetization, magnetic anomalies at the Earth's surface are damped at long wavelengths. Areas of the magnetic data must not exceed $100 \times 100 \mathrm{~km}$ (Maus et al., 1997). Owing to the long wavelength anomalies with deepening sources and the large size of the study area (450 $\mathrm{km} \times 495 \mathrm{~km}$ ), the filtered data were divided into 80 overlapping blocks, each being $90 \times 90 \mathrm{~km}$ in size, following Okubo et al. (1985), Tsokas et al. (1998), and Stampolidis and Tsokas (2002) (Fig. 3). Each block was overlapped fifty percent with the adjacent block.

We first calculated the radially averaged log power spectrum of each block utilizing once again the FFTFIL (Hildenbrand, 1983). To estimate the centroid, $z_{0}$, the spectrum divided by " $|s|$ " of each block was drawn against the wavenumber. $z_{0}$ was then estimated from the slope of the longest wavelength part of the spectrum. In the second step, the spectrum was drawn against the wavenumber in order to estimate the top depth, $z_{t}$, from the second longest wavelength part of the spectrum. Figure 4 shows examples of the power spectrum of magnetic anomaly data of block 63 (see Fig. 3 for location of the block). From the centroid depth of $10.3 \mathrm{~km}$ and the depth to the top of $2.9 \mathrm{~km}$, the CPD is calculated as $17.7 \mathrm{~km}$ for this block by means of the Equation. The eighty estimates of the CPD of SW Turkey range from 9 to $20 \mathrm{~km}$ below ground level. Figure 5 shows the CPD map of SW Turkey which is constructed from the CPD estimates by using the standard gridding routine.

\section{Heat Flow Estimates from CPD}

We compared our CPD estimations with the tectonic setting, temperature gradient and heat flow data in order to test their accuracy. The E-W trending deep CPD zone in the southern area is located beneath the Tauride mountain range, where a few low heat flow values (66 and $81 \mathrm{mWm}^{-2}$ ) were measured previously based on silica geothermometry (İlkışık, 1995) and low heat flow contours (20-60 $\mathrm{mWm}^{-2}$ ) in Fig. 5 (Tezcan and Turgay, 1989). The shallow CPD of about 9-11 km obtained from blocks numbered 29, 30, 39, 40 are compatible with the temperature gradient data and high heat flow. İlkışık et al. (1997) found an average geothermal gradient of $6.8^{\circ} \mathrm{C} / 100 \mathrm{~m}$ in 


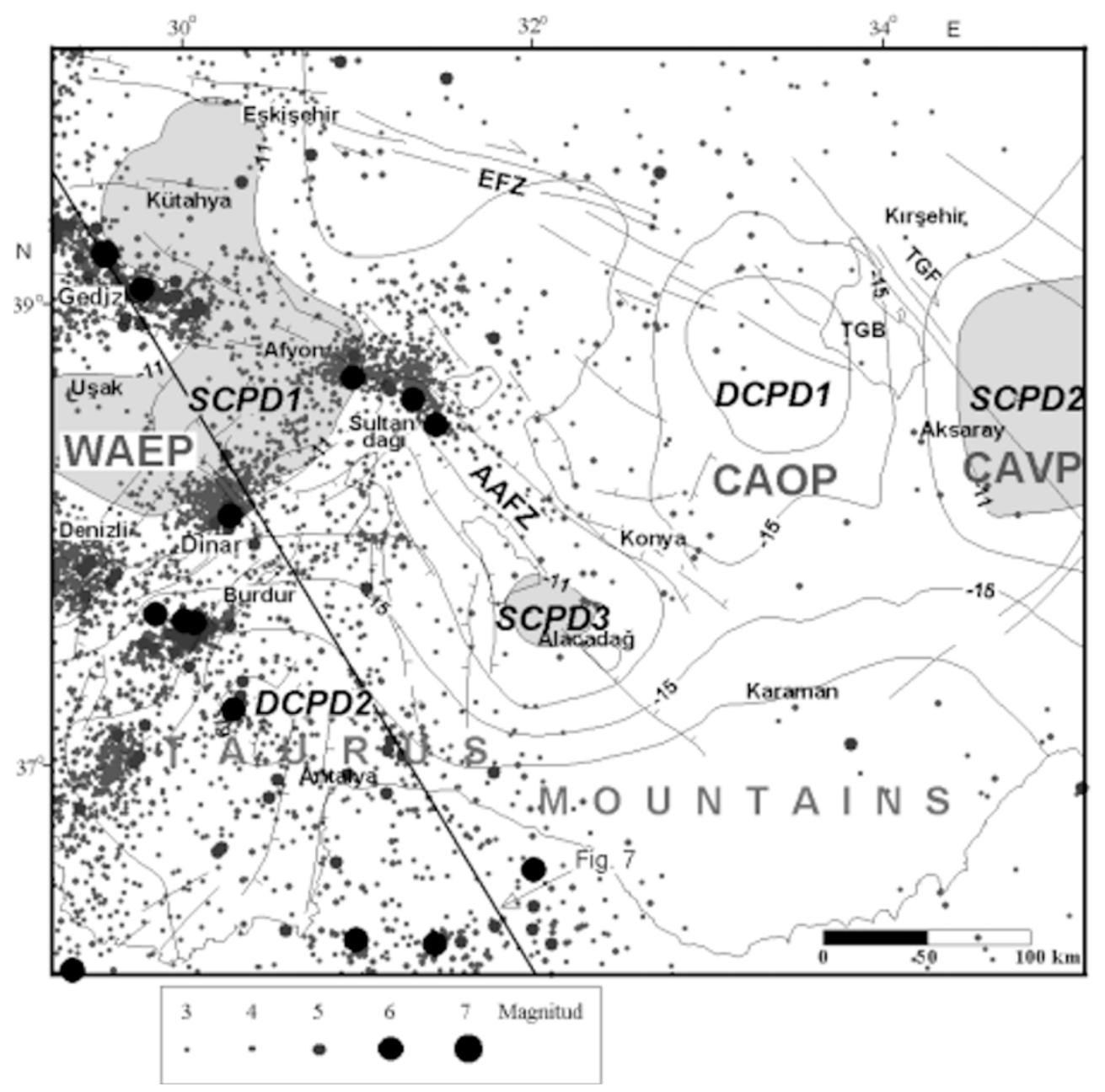

Fig. 6. Seismicity of the study area for the period 1964-2004 (after data IRIS). The CPD contours are plotted on the map for comparison. Location of the cross-section in Fig. 7 is marked as a thin solid line. Abbreviations: WAEP, West Anatolian Extensional Province; CAVP, Central Anatolian Volcanic Province; CAOP, Central Anatolian Ova Province; AAFZ, Afyon-Akşehir Fault Zone; EFZ, Eskişehir Fault Zone; TGF, Tuz Gölü Fault; TGB, Tuz Gölü Basin. See text for explanation.

this area. They also found a high averaged heat flow value of $158 \pm 35 \mathrm{mWm}^{-2}$ using both the silica and gradient techniques in the CAVP. We found a high temperature gradient of ca. $64^{\circ} \mathrm{C} / \mathrm{km}$ and high heat flows of higher than ca. 112 $\mathrm{mWm}^{-2}$ from the CPD (Fig. 5). This area is dominated by volcanic peaks belonging to the CAVP. These confirmations show that our estimations are reasonable values for the study area. More confirmations will be discussed in the Discussions and Conclusion sections of this paper.

Determination of CPD is one of the methods used to estimate temperature gradients in the crust. Thermal gradient of each block is calculated assuming that rocks are dominated by magnetite which has the Curie temperature of $580^{\circ} \mathrm{C}$. The thermal gradient data varying from $580 / 20$ to $580 / 9^{\circ} \mathrm{C} / \mathrm{km}$ reveal high vertical temperature gradients in SW Turkey.

We have correlated the estimated CPD and corresponding geothermal gradient values and the previous heat flow data (Tezcan and Turgay, 1989; İlkışık, 1995; İlkışık et al., 1997). We also calculated the corresponding heat flow values using $k=2.12 \mathrm{~W} / \mathrm{m}^{\circ} \mathrm{C}$, which is the mean thermal conductivity inferred from the laboratory measurements on a number of rock samples collected from the study area (Dol- maz, 2004). İlkışık et al. (1997) obtained an approximate effective thermal conductivity value of $2.106 \mathrm{~W} / \mathrm{m}^{\circ} \mathrm{C}$ in the CAVP. The average thermal conductivity of $2.1 \mathrm{~W} / \mathrm{m}^{\circ} \mathrm{C}$ was also used to calculate preliminary heat flow values of Turkey (Tezcan and Turgay, 1989). When preparing the corresponding heat flow data, we used the heat flow equation. Locations of the Neogene volcanics, geothermal springs and the Quaternary volcanoes are plotted on Figure 5 to make comparisons with the CPD and heat flow variations across the region. Overall, there is a good correlation of the known geothermal springs and the recently active volcanoes with the positive thermal anomaly regions in SW Anatolia.

\section{Correlation of Seismic Activity with Thermal Structure of the Crust in SW Anatolia}

The earthquakes that occurred during 1964 to 2004 were plotted on the CPD variation map with an aim of comparing the seismicity and the thermal structure of the study area (Fig. 6). The earthquakes in the study area have been investigated by several studies (Canıtez and Üçer, 1967; McKenzie, 1972; Eyidoğan and Jackson, 1985; Ambraseys, 1988; Eyidoğan, 1988; Taymaz and Price, 1992; Eyidoğan and Barka, 1996; Pınar, 1998). The seismic data were 


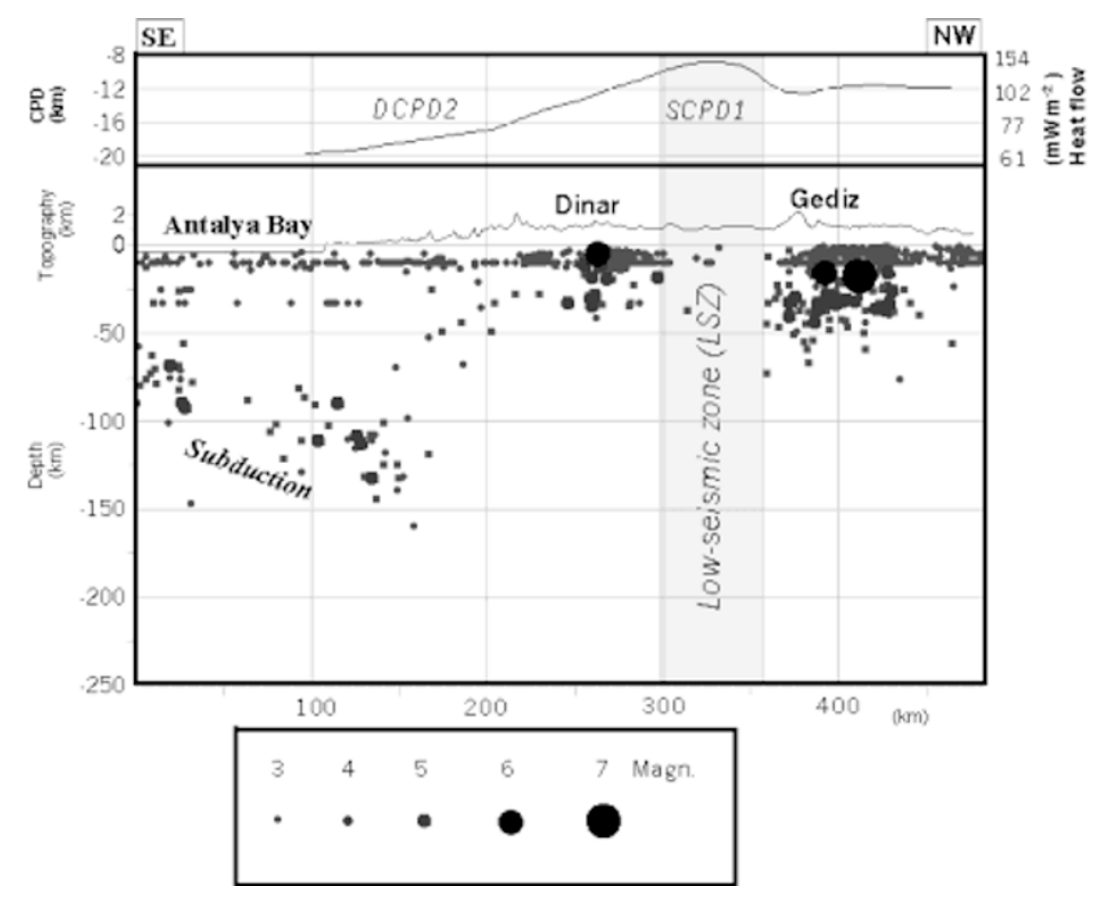

Fig. 7. A NW-SE trending cross-section showing the variation of CPD, topography and the hypocenters of the earthquakes that occurred between 1964 and 2004. Overall the CPD deepens towards the active margin of Eurasia, interpreted as the cooling affect of the subducting old crust. Note that the thermal anomaly region is located between the two intense seismic zone and is characterized by a low seismic zone. See Fig. 6 for the location of the cross-section.

taken from the IRIS (Incorporated Research Institutions for Seismology) catalogues and the earthquakes of magnitude greater than 3 were used only. Overall, the seismic activity is confined to narrow extensional fault zones in the WAEP (approximately west of the longitude $32^{\circ} \mathrm{E}$; Fig. 6) but a scatter is observed over a wide region in the CAOP. Dense earthquakes in the Antalya area are of deep origin and are thought to be associated with the northward subduction of the African Plate (Fig. 7). There is hardly any seismic activity within the Taurides between the longitudes of $32^{\circ}$ and $34^{\circ}$.

The E-W trending portion of the shallow CPD region between Uşak and Afyon (SCPD1) lies in a low seismicity zone (LSZ), which is between the two high seismic activity zones of Dinar-Denizli in the south and Gediz in the north (Fig. 6). The earthquakes near the town of Sultandag1 in SW Turkey occurred at the near east edge of the inferred western thermal structure (SCPD1; Fig. 6). Furthermore, the southern edge of the inferred western thermal structure (SCPD1) has been damaged repeatedly by large earthquakes (the earthquakes around the city of Dinar and Denizli in Fig. 6). Earthquakes also occurred around the city of Gediz and Eskişehir close to the margin of the inferred western thermal structure (SCPD1). It is interesting to note that the NW-SE trending part of the shallow CPD region between Afyon and Kütahya (SCPD1) cuts the AAFZ. There is hardly any seismic activity in the overlap region (SCPD1) while intense seismic activity has been recorded on this fault zone beyond the overlap area (Fig. 6). Vertical distribution of the focal depths of the earthquakes and position of the CPD are shown in a cross-section taken along a $40 \mathrm{~km}$ wide, NW-SE trending profile (Fig. 7). The crosssection clearly shows the slab position and illustrates the deep CPD (DCPD2) and weak heat flow anomalies in the south. To the north, the shallower CPD (SCPD1) estimates of about $9-11 \mathrm{~km}$ (the higher heat flow anomalies of ca. $112 \mathrm{mWm}^{-2}$ ) are observed in the LSZ of Uşak-Afyon between the Gediz and Dinar towns, where intense earthquake distributions are observed (Fig. 7).

\section{Discussions}

Figure 5 shows two shallow CPD regions, the one in the west (SCPD1) is located in the WAEP and the other in the east (SCPD2) is located beneath the CAVP. These two inferred thermal anomaly regions are separated by a NNWSSE trending belt of deep CPD region (DCPD1) located beneath the CAOP (Fig. 8). A local thermal dome is also present to the SW of Konya (SCPD3). Southern part of the study area (i.e. the Taurides) towards the active margin is characterized by a cooler crust. In this section, we discuss the CPD variations across SW Turkey and compare them with previous geophysical data involving crustal structures and seismicity.

a) Western Anatolian Extensional Province (WAEP) The shallow CPD region in the WAEP (SCPD1) trends E$\mathrm{W}$ between Uşak and Afyon, but then bends sharply into NW-SE direction between Afyon and Kütahya and then into NE-SW direction between Kütahya and Eskişehir. The eastern edge of this shallow CPD region corresponds in part to the AAFZ and the Eskişehir Fault Zone (EFZ; in Fig. 6). The shallow CPD region in the Uşak-Afyon zone (SCPD1) is the eastern part of a larger thermal anomaly region located between the Aegean Sea in the west to Uşak in the east (Dolmaz et al., 2005). The size of this larger thermal anomaly is more than $450 \mathrm{~km}$ in E-W and ca. 100 $\mathrm{km}$ in N-S directions. 
The lower crust at Uşak exhibits low velocities (ca. 3.5 $\mathrm{kms}^{-1}$ ) for the continental crust (Saunders et al., 1998). These lower velocities suggest the presence of silica-rich material in the lower crust beneath western Turkey (Saunders et al., 1998). The shallow CPD field in the WAEP of the study area (SCPD1) is characterized by a thinner upper crust and a highly conductive lower crust $(10 \Omega \mathrm{m})$ beneath. The top boundary of the conductive lower crust is rather shallow in this area (Gürer et al., 2001, 2004). The resistivity model of northeast Japan by MT data sets shows conductive zones under a geothermal field, where the CPD are shallow (Ogawa, 1992; Ogawa et al., 2001). Tanaka et al. (1999) suggested that CPD estimates are shallower than about $10 \mathrm{~km}$ at volcanic and geothermal areas. Hyndman and Shearer (1989) also pointed out a relationship between the top of the low resistivity area and surface heat flow. This conductive layer conforms well to our shallow CPD of 9-11 km and shallow earthquake focal depths. The shallow CPD area in the Uşak-Afyon zone (SCPD1) is in good agreement with the depth to the top of the conductive and low velocity lower crust. The shallow CPD estimates of 9-11 km (high heat-flows) on the western part of the study area (blocks numbered 12, 22, 23, 31, 32, 33 in Fig. 3) are approximately correlated with hot water springs, important geothermal fields and Upper Tertiary-Quaternary volcanics (Fig. 5). The temperature of the top of the reflective lower crust and the low electrical resistivity is about $300-450^{\circ} \mathrm{C}$ in the continental crust (Ito, 1999). It is interpreted that the CPD might be placed very close to the top of the reflective lower crust.

The transition from seismic to aseismic zones is interpreted as a thermal effect (Hyndman and Wang, 1993). The seismic-aseismic boundary is also thought to be related to the brittle-ductile boundary in the crust (Kobayashi, 1976; Sibson, 1982; Doser and Kanamori, 1986; Ito, 1990; Tanada, 1999). Although the seismic network of this area is insufficient to determine the seismogenic layer, the seismogenic layer of the area (the Uşak-Afyon low seismicity zone) between Dinar and Gediz seems to be rather shallow and therefore may not accumulate enough stress for a large earthquake to occur, instead deformation takes place in a ductile manner (Fig. 7). Dense earthquakes seem to occur in areas where the lateral gradients of the CPD are steep. These areas may correspond to the boundaries between high and low thermal regions of the crust. Thus, the variations in the seismic activity may be closely related to thermal structures of the crust. Shallow cutoff depths of seismicity can also be found in some geothermal areas in Japan. These facts indicate that the changes in the thickness of the seismogenic layer strongly depend on temperature (Ito, 1999).

b) Central Anatolian Volcanic Province (CAVP) The eastern shallow CPD region (SCPD2) is located in near the Aksaray area (Figs. 5 and 6). This area is a vast volcanic province of Neogene-Quaternary age, erupted on a Cretecaeous metamorphic basement (the CAVP; Pasquare et al., 1988; Toprak and Göncüoğlu, 1993; Le Pennec et al., 1994; Tankut et al., 1998; Aydar and Gourgaud, 1998, 2002). The volcanic centers are great andesitic-basaltic strato-volcanoes. Mount Hasan, Ciftlik and Melendiz near Aksaray were active volcanoes in the recent geological peri- ods. Mount Hasan is an andesitic strato-cone with a height of $3253 \mathrm{~m}$, whereas the average topography of the area is about $1300 \mathrm{~m}$. Moreover, many Quaternary volcanic centers are concentrated in a zone between Acıgöl and Niğde (İlkışık et al., 1997). The shallow CPD estimates (and corresponding high heat flow anomalies of more than 112 $\mathrm{mWm}^{-2}$ ) in the eastern part of the study area (SCPD2) coincide with the site of this volcanism. This zone of shallow CPD (high heat flow) is also characterized by numerous hot water springs. High regional heat flow $\left(143 \mathrm{mWm}^{-2}\right)$ is observed in a borehole in the Ihlara Valley of the CAVP (İlkış1k et al., 1997). Using the method of Bullard (1939), they also obtained an approximate value of $132 \mathrm{mWm}^{-2}$ in the same hole. The heat flow map of Tezcan and Turgay (1989) shows high heat flow anomaly contours of 90-100 $\mathrm{mW} / \mathrm{m}^{2}$ in the CAVP (Fig. 5). These heat flow values are well correlated with our corresponding high heat flow values around the CAVP.

c) Alacadag Area The local thermal dome in SW Konya (SCPD3) is found beneath a small volcanic province of Late Miocene-Pliocene age, termed the ErenlerdagAlacadag Massif (Keller et al., 1977). The Alacadag volcanic rocks represent arc-type, high-K calc-alkaline magmatism with a considerable crustal contamination (Temel et al., 1998). Absence of Quaternary volcanoes in the Alacadag area seems strange concerning the thermal dome underneath. This small volcanic province is located ca. 130 $\mathrm{km}$ above the subducting slab of the African Plate. The slab breaks off or disappears further NE since no hypocenter has been detected. The vertical distance of $130 \mathrm{~km}$ is within the range of depths that arc magmatism develops above a subducting slab at many modern active margins (Isacks and Barazangi, 1977; Fowler, 1990). Thus, the local thermal dome to the SW of Konya (SCPD3) may indicate presence of active, arc-type magma chambers, emplaced at shallow levels in the crust at this locality.

d) Taurides The deep CPD (DCPD2) estimates in southern part of the study area clearly coincide with the Taurus Mountains. From inversion of the MT data of a NWSE profile in SW Anatolia under the Taurus Mountains, a very highly resistive ( $>2000 \Omega \mathrm{m}$ ) thicker upper crust is observed while the lower crust is much thinner (Gürer et al., 2004). The deep CPD estimates between 15 and $20 \mathrm{~km}$ (contrary to low heat-flows at block numbers 52, 53, 62, 63, 72 in Fig. 3) are in good agreement with this high resistivity zone. In the southern part of the study area, Sn propagates efficiently, indicating that cold lithosphere is present beneath the Taurus Mountains (Gök et al., 2000). We think that this area is influenced by the cooling effect of the subducting slab.

e) Central Anatolian Ova Province (CAOP) Between the two shallow CPD fields (SCPD1) in the WAEP and (SCPD2) the CAVP, a $100 \mathrm{~km}$ wide belt of relatively deep CPD region (about 15-17 km) extending approximately in a NNW-SSE direction (DCPD1) is present (Fig. 8). This zone (DCPD1) is located between the longitudes of $32^{\circ}$ and $34^{\circ} \mathrm{E}$ within the CAOP and shows little and dispersed seismic activity (Fig. 6). There is a thick (ca. $10 \mathrm{~km}$ ) Neogene sedimentary basin (the TGB; Gürbüz and Evans, 1991) above this low heat flow zone. This area has 


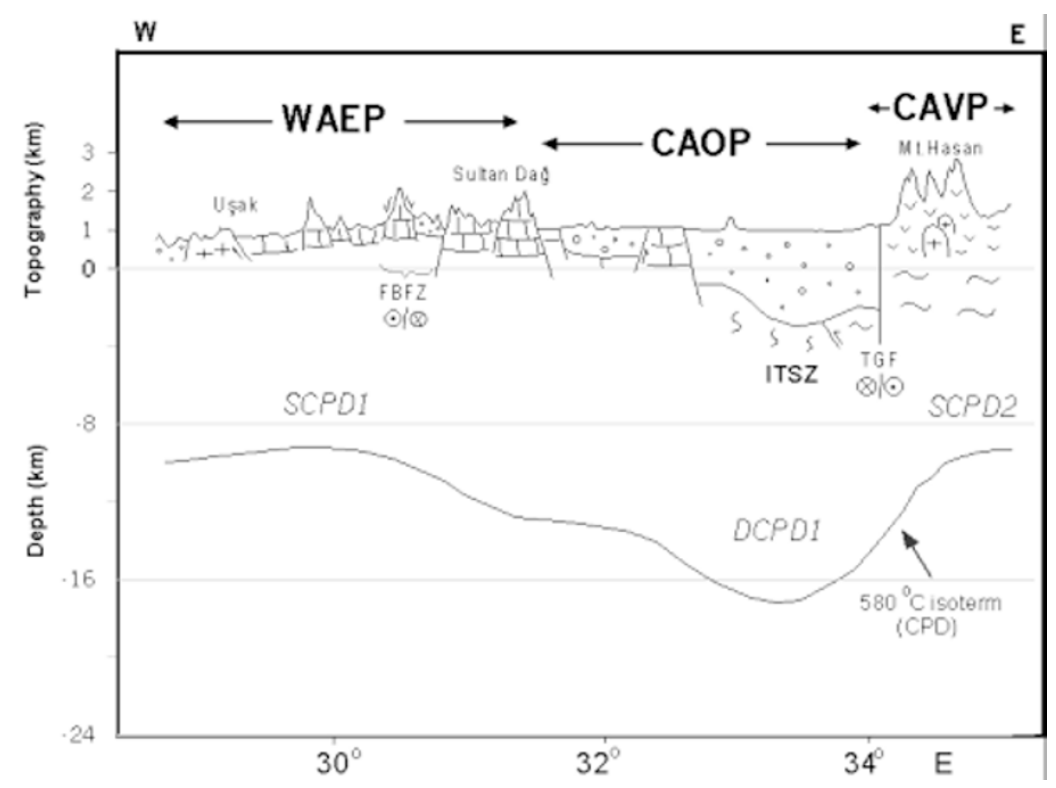

Fig. 8. Schematic geological cross-section and CPD variation across SW Turkey between Uşak and Aksaray. Abbreviations: WAEP, West Anatolian Extensional Province; CAVP, Central Anatolian Volcanic Province; CAOP, Central Anatolian Ova Province; FBFZ, Fethiye-Burdur Fault Zone; TGF, Tuz Gölü Fault; ITSZ, Inner-Tauride suture zone. See text for explanation.

been tectonically less active and in general has had little or no intrusive or extrusive activity, although nearby the CAVP was the site of voluminous Neogene-Queternary volcanic activity. Low heat flow anomaly contours of $40-70 \mathrm{~mW} / \mathrm{m}^{2}$ are present in this area (Fig. 5; Tezcan and Turgay, 1989).

The NNW-SSE trending low heat flow zone (DCPD1) separates the seismically active extensional province to the west from the compressional province to the east. Palaeomagnetic data on the Neogene volcanics on both sides of this zone indicates anti-clockwise rotations in the west and clockwise rotations in the east of this region (Gürsoy et al., 2003). A zone of weakness accommodating the differential block rotations must be present underneath the TGB (Fig. 5 and 6). The Late Mesozoic-Early Tertiary Inner-Tauride suture zone (Şengör and Yılmaz, 1981) is the most obvious weakness zone in this area. This suture zone is now mainly buried under the deposits of the TGB. Thermal cooling of this zone can be attributed either to crustal thickening, inherited from the Tertiary times, or to rapid subsidence related to deposition of the TGB sediments.

We think that while the Miocene to recent crustal extension culminated in formation of a thermal dome (SCPD1) in the west, the un-extended region towards the east remained colder. Magmatism in Quaternary beneath the CAVP resulted in formation of the second thermal dome (SCPD2) in the easternmost area by emplacement of the melts at shallow crustal levels. The volcanoes in this region were fed by these shallow magma chambers (Aydar and Gourgaud, 1998, 2002). Thus, the area between the extended region and the thickened region (i.e. the CAVP) remained colder. Deposition of $10 \mathrm{~km}$-thick sediments in the subsiding TGB further contributed to depression of the CPD (Fig. 5 and 6). The CPD may have been much deeper in the recent geological past in this area and the present CPD may only reflect a stage in which the crust is trying to reach a thermal reequilibrium.
In summary, perturbations in thermal structure of the crust in SW Turkey are governed by the tectonic setting and associated magmatism. Both the litospheric thinning and post-collisional magmatism appear to create a similar thermal structure, but the size of the thermal anomalies created may vary considerably.

\section{Conclusion}

Spectral analysis of the aeromagnetic data was used, in this study, to infer thermal structure of the crust in SW Turkey. Two regional and one local shallow CPD zones were found. The two regional thermal domes are located in the west and east of the study area and are separated by a zone of NNW-SSE trending deep CPD. N-S litospheric stretching and associated upwelling of astenosphere are responsible for generation of the western thermal dome in Western Anatolia. Comparison of the thermal structure with the seismic activity indicated that low seismicity zones within high seismicity regions are characterized by hotter crust and higher heat flows. Major earthquakes of extensional and/or strike-slip origin occur only along the steeper margins of regional thermal domes.

The eastern thermal dome is located in the Central Anatolian Volcanic Province. Several Quaternary volcanoes are located in this area, forming summits of $>3000 \mathrm{~m}$ above sea level. The Central Anatolian Volcanic Province shows little seismicity, indicating low internal deformation of the crust. The eastern thermal dome is thought to be related to presence of silicate melts of crustal origin in the shallower levels of the thickened crust in Central Anatolia.

A local thermal dome is found beneath a Neogene volcanic province in Alacadağ area. Although there is not an active volcano in this area, a location of $130 \mathrm{~km}$ above the present subducting slab suggests that arc-type silicate melts may have emplaced at shallow crustal depths at this location. 
The deep CPD region separating the west and east thermal domes is located in the Central Anatolian Ova Province. A crustal zone of weakness may be present in this area, beneath the large Neogene sedimentary basin fill. Crustal thickening and/or rapid subsidence is thought to be responsible from thermal cooling along this zone. The Tauride belt in the southern part of the study area is represented by deep CPD. This area is close to the AfricanEurasian collision zone, represented by Cyprus-Hellenic trench. Cooling affect of the subducting slab is thought to be dominating factor in governing the thermal structure of the crust beneath the Taurides.

This study has shown that both tectonics and magmatism play an important role in generating the thermal structure of the crust above subduction zones. The Curie isotherm may shallow up to similar depths during an extensional event or during emplacement of silicate melts at shallow crustal levels. However, the sizes of the resulting thermal domes vary considerably. Presence of regional thermal domes is thought to aid rapid lithospheric stretching and associated crustal thinning as in the case of Western Anatolia.

Acknowledgments. This work was supported by the Research Fund of Istanbul University (project no: T4423072002). We thank Dr. A. Tanaka and Dr. J. Joseph for their constructive review on the manuscript. We also thank MTA for permission of use of the aeromagnetic data and IRIS for use of the earthquake data.

\section{References}

Ambraseys, N. N., Engineering seismology, Earthquake Eng. Struct. Dyn., 17, 1-105, 1988 .

Anastasakis, G. and G. Kelling, Tectonic connection of the Hellenic and Cyprus arcs and related geotectonic elements, Mar. Geol., 97, 261-277, 1991.

Andrew, T. and A. H. F. Robertson, The Beyşehir-Hoyran-Hadim nappes: genesis and emplacement of Mesozoic marginal and oceanic units of the northern Neotethys in southern Turkey, Journal of the Geological Society, 159, 529-543, 2002.

Ates, A., P. Kearey, and S. Tufan, New gravity and magnetic maps of Turkey (Research Note), Geophys. J. Int., 136, 499-502, 1999.

Aydar, E. and A. Gourgaud, The geology of Mount Hasan stratovolcano, central Anatolia, Turkey, J. Volcan. Geoth. Res., 85, 129-152, 1998.

Aydar, E. and A. Gourgaud, Garnet-bearing basalts: an example from Mt. Hasan, Central Anatolia, Turkey, Mineralogy and Petrology, 75, 185201, 2002.

Aydın, İ. and H. İ. Karat, Türkiye aeromagnetik haritalarına genel bir bakış, Jeofizik, 9, 41-44, 1995 (in Turkish with English abstract).

Badalyan, M., Geothermal features of Armenia: a country update, Proceedings World Geothermal Congress 2000, pp. 71-76, KyushuTohoku, Japan, 2000.

Banerjee, B., P. B. V. Subba Rao, Gautam Gupta, E. J. Joseph, and B. P. Singh, Results from a magnetic survey and geomagnetic depth sounding in the post-eruption phase of the Barren Island volcano, Earth Planets Space, 50, 327-338, 1998.

Barka, A. A., The North Anatolian Fault Zone, Annales Tectonicae, 6, 164-195, 1992.

Bhattacharyya, B. K. and L. K. Leu, Spectral analysis of gravity and magnetic anomalies due to two dimensional structures, Geophysics, 40, 993-1013, 1975.

Blakely, R. J., Curie Temperature Isotherm Analysis and Tectonic Implications of Aeromagnetic Data from Nevada, J. Geophys. Res., 93, 1181711832, 1988.

Blakely, R. J. and S. Hassanzadeh, Estimation of depth to magnetic source using maximum entropy power spectra, with application to the PeruChile Trench, in Nazca Plate: Crustal Formation and Andean Convergence, Geolog. Soc. America Memoir, 154, 667-682, 1981.

Bozkurt, E., Neotectonics of Turkey—a synthesis, Geodinamica Acta, 14, 3-30, 2001.

Bullard, E. C., Heat flow in South Africa, Proc. R. Soc. London. Ser. A.,
173, 474-502, 1939.

Byerly, P. E. and R. H. Stolt, An attempt to define the curie point isotherm in northern and central Arizona, Geophysics, 42, 1394-1400, 1977.

Canıtez, N. and B. Üçer, Computer determinations for the fault-plane solutions in and near Anatolia, Tectonophysics, 4, 235-244, 1967.

Connard, G., R. Couch, and M. Gemperle, Analysis of aeromagnetic measurements from the cascade range in central Oregon, Geophysics, 48, 376-390, 1983.

Çemen I., M. C. Göncüoğlu, and K. Dirik, Structural Evolution of the Tuzgölü Basin in Central Anatolia, Turkey, The Journal of Geology, 107, 693-706, 1999.

Dewey, J. F., M. R. Hempton, W. S. F. Kidd, F. Şaroglu, and A. M. C. Şengör, Shortening of continental lithosphere: the neotectonics of eastern Anatolia- a young collision zone, Collisional Tectonics, edited by M. O. Coward and A. C. Ries, Geol. Soc., London, Spec. Pub., 19, 3-36, 1986.

Dolmaz, M. N., Determination of Curie Point Depths of Southern Part of Western Anatolia and Their Correlation With Geodynamic Events, Ph.D. Thesis, Istanbul University, Turkey (unpubl.), 2004 (in Turkish with English abstract).

Dolmaz, M. N., Z. M. Hisarli, T. Ustaömer, and N. Orbay, Curie point depths based on spectrum analysis of the aeromagnetic data, West Anatolian Extensional Province, Turkey, Pure and Appl. Geop., 162, 571590, 2005.

Doser, D. I. and H. Kanamori, Depth of seismicity in the Imperial Valley region (1977-1983) and its relationship to heat flow, crustal structure and the October 15, 1979 earthquake, J. Geophys. Res., 91, 675-688, 1986.

Eyidoğan, H., Rates of crustal deformation in western Turkey as deduced from major earthquakes, Tectonophysics, 148, 83-92, 1988.

Eyidoğan, H. and A. Barka, The 1 October 1995 Dinar earthquake, SW Turkey, Terra Nova, 8, 479-485, 1996.

Eyidoğan, H. and J. Jackson, A seismological study of normal faulting in the Demirci, Alasehir and Gediz earthquakes of 1969-1970 in western Turkey: implications for the nature and geometry of deformation in the continental crust, Geophys. J. R. Astr. Soc., 81, 569-607, 1985.

Fowler, C. M. R., The Solid Earth: An Introduction to Global Geophysics, 472 pp., Cambridge, U.K., 1990.

Gök, R., N. Türkelli, E. Sandvol, D. Seber, and M. Barazangi, Regional wave propagation in Turkey and surrounding regions, Geophys. Res. Lett., 27, 429-432, 2000.

Görür, N., F. Y. Oktay, İ. Seymen, and A. M. C. Şengör, Paleotectonic evolution of the Tuzgölü basin complex, Central Turkey: sedimentary record of a Neo-Tethyan closure, in The Geological Evolution of the Eastern Mediterranean, edited by J. E. Dixon and A. H. F. Robertson, Geol. Soc., London, Spec. Pub., 17, 467-482, 1984.

Gürbüz, C. and J. R. Evans, A seismic refraction study of the western Tuz Gölü basin, central Turkey, Geophys. J. Int., 106, 239-251, 1991.

Gürer, A., O. F. Gürer, A. Pince, and O. M. İlkışık, Conductivity structure along the Gediz graben, West Anatolia, Turkey: Tectonic implications, Int. Geol. Rev., 43, 1129-1144, 2001.

Gürer, A., M. Bayrak, O. F. Gürer, and O. M. İlkışık, The deep resistivity structure of southwestern Turkey: Tectonic implications, Int. Geol. Rev., 46, 655-670, 2004.

Gürsoy, H., J. D. A. Piper, and O. Tatar, Neotectonic deformation in the western sector of tectonic escape in Anatolia: paleomagnetic study of the Afyon region, central Turkey, Tectonophysics, 374, 57-79, 2003.

Hildenbrand, T. G., FFTFIL: A Filtering Program Based on Twodimensional Fourier Analysis, U.S.G.S. Open File Report, 83-237, 1983.

Hisarli, Z. M., Determination of Curie Point Depths in Western Anatolia and Related with the Geothermal Areas, Ph.D. Thesis, Istanbul University, Turkey (unpubl.), 1996 (in Turkish with English abstract).

Hyndman, R. D. and P. M. Shearer, Water in the lower continental crust: modeling magnetotelluric and seismic reflection results, Geophys. J., 98, 343-365, 1989.

Hyndman, R. D. and K. Wang, Thermal constraints on the zone of possible major thrust earthquake failure on the Cascadia subduction zone, $J$. Geophys. Res., 98, 2039-2060, 1993.

Isacks, B. L. and M. Barazangi, Geometry of Benioff zones: Lateral segmentation and downwards bending of the subducted lithosphere, Island arcs, deep-sea trenches and back-arc basins, edited by M. Talwani and W. C. Pitman III, Am. Geophys. Un. Maurice Ewing Series, 1, 99-114, 1977.

Ito, K., Regional variations of the cutoff depth of seismicity in the crust and their relation to heat flow and large inland earthquakes, J. Phys. Earth, 
38, 223-250, 1990 .

Ito, K., Seismogenic layer, reflective lower crust, surface heat flow and large inland earthquakes, Tectonophysics, 306, 423-433, 1999.

İlkışık, O. M., Regional Heat Flow in Western Anatolia Using Silica Temperature Estimates from Thermal Springs, Tectonophysics, 244, 175$184,1995$.

İlkışık, O. M., A. Gürer, T. Tokgöz, and C. Kaya, Geoelectromagnetic and geothermic investigations in the Ihlara Valley geothermal field, $J$. Volcan. Geoth. Res., 78, 297-308, 1997.

Keller, J., D. Jung, K. Burgath, and F. Wolf, Geologie und petrologie des Neogenen kalkalkali-vulkanismus von Konya (Erenler Dag-Alaca DagMassiv Zentral-Anatolian), Geo. Jb., B 25, 37-117, 1977.

Kobayashi, Y., A relationship between the distribution of focal depth of micro-earthquakes and surface heat flow in the southwestern Japan and central Japan, Proc. Symp. Earthquake Prediction Research, 184-193, Natl. Comm. Geophys. Seismol. Soc., Jpn., 1976 (in Japanese with English abstract).

Le Pennec, J. L., J. L. Bourdier, J. L. Froger, A. Temel, G. Camus, and A. Gourgaud, Neogene ignimbrites of the Nevsehir plateau (Central Turkey): stratigraphy, distribution and source constraints, J. Volcan. Geoth. Res., 63, 59-87, 1994.

Malin, S. R. C. and D. R. Barraclough, An algorithm for synthesizing the geomagnetic field, Computer \& Geoscience, 7, 401-405, 1981.

Maus, S., D. Gordon, and D. Fairhead, Curie temperature depth estimation using a self-similar magnetization model, Geophys. J. Int., 129, 163$168,1997$.

McClusky, S., S. Balassanian, A. Barka, C. Demir, S. Ergintav, I. Georgiev, O. Gurkan, M. Hamburger, K. Hurst, H. Kahle, K. Kastens, G. Kekelidze, R. King, V. Kotzev, O. Lenk, S. Mahmoud, A. Mishin, M. Nadariya, A. Ouzounis, D. Paradissis, Y. Peter, M. Prilepin, R. Reilinger, I. Sanli, H. Seeger, A. Tealeb, M. N. Toksöz, and G. Veis, Global Positioning System constraints on plate kinematics and dynamics in the eastern Mediterranean and Caucasus, J. Geophys. Res., 105, 5695-5719, 2000.

McKenzie, D. P., Active tectonics of Mediterranean region, Geophys. J. R. Astr. Soc., 30, 109-185, 1972.

McKenzie, D. P., Active tectonics of the Alpine-Himalayan belt: the Aegean Sea and surrounding regions, Geophys. J. R. Astr. Soc., 55, 217254,1978

Nagata, T., Rock Magnetism, 350 pp., Maruzen, Tokyo, 1961.

Ogawa, Y., Deep crustal resistivity structure revealed by wide-band magnetotellurics; Tohoku and Hokkaido region, Ph.D. Thesis, Univ. of Tokyo, Japan, 1992.

Ogawa, Y., M. Mishina, T. Goto, H. Satoh, N. Oshiman, T. Kasaya, Y. Takahashi, T. Nishitani, S. Sakanaka, M. Uyeshima, Y. Takahashi, Y. Honkura, and M. Matsushima, Magnetotelluric imaging of fluids in intraplate earthquake zones, NE Japan back arc, Geophys. Res. Lett., 28, 3741-3744, 2001.

Okubo, Y. and T. Matsunaga, Curie point depth in northeast Japan and its correlation with regional thermal structure and seismicity, J. Geophys. Res., 99(B11), 22363-22371, 1994.

Okubo, Y., J. R. Graf, R. O. Hansen, K. Ogawa, and H. Tsu, Curie point depths of the island of Kyushu and surrounding areas, Japan, Geophysics, 53, 481-494, 1985.

Okubo, Y., H. Tsu, and K. Ogawa, Estimation of curie point temperature and geothermal structure of island arc of Japan, Tectonophysics, 159, 279-290, 1989.

Özgül, N., Torosların bazı temel jeolojik özellikleri, T. J. K. Bült., 19, 6578, 1976 (in Turkish with English abstract).

Özgül, N., S. Bölükbaşı, H. Alkan, H. Öztaş, and M. Korucu, Göller bölgesinin tektono-stratigrafik birlikleri, Ozan Sungurlu Semp. Bild., edited by S. Turgut, pp. 213-237, Turkey, 1991 (in Turkish with English abstract).

Özkaya, İ., Origin of the allochthons in the Lycian belt, Southwest Turkey, Tectonophysics, 177, 367-379, 1990.

Pasquare, G., S. Poli, L. Vezzoli, and A. Zanchi, Continental arc volcanism and tectonic setting in Central Anatolia, Turkey, Tectonophysics, 146, 217-230, 1988.

Paton, S., Active normal faulting, drainage patterns and sedimentation in southwestern Turkey, Journal of the Geological Society, 149, 10311044, 1992.

Pinar, A., Source inversion of the 1 October, 1995, Dinar earthquake $(\mathrm{Ms}=6.1)$ : a rupture model with implications for seismotectonics in SW Turkey, Tectonophysics, 292, 255-266, 1998.
Reilinger, R. E., S. C. McClusky, M. B. Oral, R. W. King, M. N. Toksöz, A. A. Barka, I. Kinik, O. Lenk, and I. Sanli, Global Positioning System measurements of present-day crustal movements in the Arabia-AfricaEurasia plate collision zone, J. Geophys. Res., 102, 9983-9999, 1997.

Robertson, A. H. F., Tectonic significance of the Eratosthenes Seamount: a continental fragment in the process of collision with a subduction zone in the eastern Mediterranean (Ocean Drilling Program Leg 160), Tectonophysics, 298, 63-82, 1998.

Saunders, P., K. Priestley, and T. Taymaz, Variations in the crustal structure beneath western Turkey, Geophys. J. Int., 134, 373-389, 1998.

Shuey, R. T., D. K. Schellinger, A. C. Tripp, and L. B. Alley, Curie depth determination from aeromagnetic spectra, Geophys. J. R. Astr. Soc., 50, 75-101, 1977.

Sibson, R. H., Fault zone models, heat flow and the depth distribution of earthquakes in the continental crust of the United States, Bull. Seismol. Soc. Am., 72, 151-163, 1982.

Smith, R. B., R. T. Shuey, R. O. Freidline, R. M. Otis, and L. B. Alley, Yellowstone Hot Spot: New magnetic and seismic evidence, Geology, 2, 451-455, 1974.

Smith, R. B., R. T. Shuey, J. R. Pelton, and J. P. Bailey, Yellowstone hot spot: Contemporary tectonics and crustal properties from earthquake and aeromagnetic data, J. Geophys. Res., 82, 3665-3676, 1977.

Spector, A. and F. S. Grant, Statistical models for interpreting aeromagnetic data, Geophysics, 35, 293-302, 1970.

Stampolidis, A. and G. N. Tsokas, Curie Point Depths of Macedonia and Thrace, N. Greece, Pure and Appl. Geop., 159, 2659-2671, 2002.

Şengör, A. M. C. and Y. Yılmaz, Tethyan evolution of Turkey: a plate tectonic approach, Tectonophysics, 75, 181-241, 1981.

Şengör, A. M. C., N. Görür, and F. Şaroğlu, Strike-slip faulting and related basin formation in zones of tectonic escape: Turkey as a case study, Strike-slip Faulting and Basin Formation, edited by K. T. Biddle and N. Christie-Blick, Soc. Econ. Paleon. Min. Spec. Pub., 37, 227-264, 1985.

Şimşek, Ş., An Overview of Geothermal Developments in Turkey, ITIT International Symposium extended abstracts, 17-23, Tokyo, Japan, 2001.

Tanada, T., Seismicity in the northeast area of Izu Peninsula, Japan, comparing with three-dimensional velocity structure and temperature distribution of geothermal water, Tectonophysics, 306, 449-460, 1999.

Tanaka, A., Y. Okubo, and O. Matsubayashi, Curie point depth based on spectrum analysis of the magnetic anomaly data in East and Southeast Asia, Tectonophysics, 306, 461-470, 1999.

Tankut, A., M. Wilson, and T. Yihunie, Geochemistry and tectonic setting of Tertiary volcanism in the Güvem area, Anatolia, Turkey, J. Volcan. Geoth. Res., 85, 285-301, 1998.

Taymaz, T. and S. P. Price, The 1971 May 12 Burdur earthquake sequence, SW Turkey: a synthesis of seismological and geological observations, Geophys. J. Int., 108, 589-603, 1992.

Taymaz, T., J. Jackson, and D. McKenzie, Active tectonics of the north and central Aegean Sea, Geophys. J. Int., 106, 433-490, 1991.

Temel, A., M. N. Gündoğdu, and A. Gourgaud, Petrological and geochemical characteristics of Cenozoic high-K calc-alkaline volcanism in Konya, Central Anatolia, Turkey, J. Volcan. Geoth. Res., 85, 327-354, 1998.

Tezcan, A. K., Geothermal studies, their present status and contribution to heat flow contouring in Turkey, Terrestrial Heat Flow in Europe, edited by V. Cermak and L. Rybach, pp. 283-291, Springer, Berlin, 1979.

Tezcan, A. K. and İ. Turgay, Heat Flow Map of Turkey, General Directorate of Mineral Research and Exploration (MTA), Department of Geophysics Research, Ankara (unpubl.), 1989 (in Turkish).

Toprak, V. and M. C. Göncüoğlu, Tectonic control on the development of the Neogene-Quaternary Central Anatolian Volcanic Province, Turkey, Geol. J., 28, 357-369, 1993.

Tsokas, G. N., R. O. Hansen, and M. Fytikas, Curie point depth of Island of Crete (Greece), Pure and Appl. Geop., 152, 747-757, 1998.

Yılmaz Y., E. Yigitbaş, and Ş. C. Genç, Ophiolitic and metamorphic assemblages of southeast Anatolia and their significance in the geological evolution of the orogenic belt, Tectonics, 12, 1280-1297, 1993.

Vacquier, V. and J. Affleck, A Computation of average depth the bottom of the Earth's magnetic crust, based on a statistical study of local magnetic anomalies, Trans. Amer. Geophys. Union, 22, 446-450, 1941.

M. N. Dolmaz (e-mail: ndolmaz@mmf.sdu.edu.tr), T. Ustaömer, Z. M. Hisarli, and N. Orbay 